\title{
UMBILICAL CORD MANAGEMENT AND STUMP CARE IN NORMAL CHILDBIRTH IN SLOVENIAN AND CROATIAN MATERNITY HOSPITALS
}

\author{
Ana Polona Mivšek, Petra Petročnik, Metka Skubic, Teja Škodič Zakšek and Anita Jug Došler
}

University of Ljubljana, Faculty of Health Sciences, Midwifery Department, Ljubljana, Slovenia

\begin{abstract}
SUMMARY - The aim was to investigate first-care procedures for the newborn's umbilical cord at maternity hospitals in Slovenia and Croatia. The study was based on an empirical survey research approach and quantitative research paradigms and included all Slovenian $(\mathrm{n}=14)$ and all Croatian $(n=35)$ maternity hospitals. Leaders of midwifery team of 14 Slovenian and 35 Croatian labor wards were invited to participate. The study was conducted in 2013, with $67 \%$ of Slovenian and $66 \%$ of Croatian maternity hospitals having responded. A causal and non-experimental method of empirical research was used. The research instrument was a questionnaire. Descriptive statistics was used on data analysis. The independence hypothesis was tested with the $\chi^{2}$-test or Kullback $2 \hat{I}$-test. A vast majority of study wards employed delayed umbilical cord clamping, i.e. clamping the cord after pulsation had ceased. Only $10 \%$ of Slovenian in comparison with $36.4 \%$ of Croatian maternity hospitals practiced dry cord care. Others applied disinfectant on the cord, in Slovenia most frequently 6\% potassium permanganate, and in Croatia a combination of octenidine and phenoxyethanol. Most Croatian maternity wards (95.7\%) still covered the stump, while it was not regular practice in Slovenia. The authors estimate that the prevailing Slovenian and Croatian practices in regard to cord clamping are in accordance with the evidence, while improvements could be made regarding stump care, since dry cord care is the recommended method.
\end{abstract}

Key words: Infant, newborn; Umbilical cord; Hospitals, maternity; Slovenia; Croatia; Empirical research; Midwifery; Disinfectants; Potassium permanganate; Octenidine; Phenoxyethanol

\section{Introduction}

First care of the newborn has a significant impact on the newborn's health ${ }^{1}$. The newborn's status is also affected by the procedures applied in the third stage of labor ${ }^{2}$. The umbilical cord and the placenta can be viewed as a link between the child's intra- and extrauterine life; therefore, the management of the third stage of labor, especially the procedures for umbilical cord and immediate stump care, can affect the quality of the child's entrance to the world. This study investi-

Correspondence to: Ana Polona Mivšek, PbD, Faculty of Health Sciences, Midwifery Department, Zdravstvena pot 5, 1000 Ljubljana, Slovenia

E-mail: polona.mivsek@zf.uni-lj.si

Received November 9, 2015, accepted June 16, 2016 gated the practices of Slovenian and Croatian maternity hospitals regarding umbilical cord and umbilical stump management as one of the procedures of first care for the newborns and compared the findings with the evidence-based literature review findings.

\section{Third stage of labor}

The third stage of labor includes separation and delivery of the placenta and membranes. This process can be facilitated in two ways, either by supporting the physiological process or by using active management techniques. The physiological management, where the process is uninterrupted with interventions, is a variable term for referring to the natural, expectant or physiological third stage of labor ${ }^{3}$. It is recommended that midwives, who manage normal deliveries at term, 
promote physiological third stage of labor, however, it is inter-connected with many factors such as normality of the pregnancy, uncomplicated birth ${ }^{2}$, and also with physiologically led first and second stage of labor ${ }^{4}$.

In the expectant management of the third stage of labor, normal, physiological mechanisms of labor are supported ${ }^{2}$. The study by Begley et al. ${ }^{2}$ found postpartum hemorrhage in less than $4 \%$ of deliveries with expectant management of the third stage of labor. The main principle of this approach is that the placenta is not clamped until pulsation has ceased ${ }^{5}$. The cord traction and counter-pressure on the abdomen are not used. The third stage that is managed spontaneously may be completed in 10 to 60 minutes. Early attachment of the baby to the breast may ease the physiological course of this stage ${ }^{2}$. Immediate umbilical cord clamping (IUCC) is part of active management of the third stage of labor ${ }^{1}$, which includes application of oxytocic drugs, early clamping and division of the umbilical cord, umbilical cord traction and abdominal pressure for delivering the placenta ${ }^{6}$ after awaiting the signs of placenta separation 7 . Moreover, umbilical cord clamping is performed in the first 30 seconds to 3 minutes after birth, regardless of whether or not the pulsation has ceased ${ }^{2}$. However, the National Institute for Health and Care Excellence (NICE) guidelines define IUCC as clamping in the first 30 seconds $^{8}$. Most of the research defines delayed umbilical cord clamping (DUCC) as clamping the umbilical cord after two to four minutes, however, some experts claim that it would be better to define it as clamping the umbilical cord after the blood flow has stopped ${ }^{9}$. The World Health Organization (WHO) supports DUCC and defines it as clamping after 1 to 3 minutes after the birth ${ }^{10}$. NICE ${ }^{8}$ recommends that for healthy newborn at term, the cord is not clamped in the first 60 seconds and that it should be clamped before five minutes, although women should be supported if they wish this to be delayed further. This document also provides guidance around the different definitions used in studies and suggests that IUCC is defined as clamping within 30 seconds of the birth and deferred cord clamping means not until at least 2 minutes after the birth ${ }^{8}$. DUCC is also supported by the International Federation of Gynecology and Obstetrics $(\mathrm{FIGO})^{11}, \mathrm{WHO}^{10}$ and $\mathrm{NICE}^{8}$, whereas similar to the American College of Obstetricians and Gynecologists $(\mathrm{ACOG})^{12}$, the Royal College of Obstetricians and
Gynaecologists (RCOG) are more cautious with the support. They write: "The cord should not be clamped earlier than is necessary, based on clinical assessment of the situation"11.

For the baby, evidence suggests that DUCC is more appropriate than IUCC for term infants ${ }^{5}$.

\section{First care of the umbilicus}

Umbilical cord represents a portal for possible entry of infection and must be observed for signs of umbilical flare ${ }^{13}$. Cord care practices are often embedded in institutional tradition, however, few data were gathered in the past regarding the most effective method ${ }^{14}$. It is true that aseptic cord care decreases cord bacterial colonization, but it does not necessarily lower the risk of infection. Besides that, aseptic cord care delays cord separation ${ }^{15}$. Few studies have reported a reduced rate of omphalitis when using antiseptic care, as claimed by Zupan et al. ${ }^{16}$. In the past, the umbilical cord stump was cleaned with different substances ${ }^{14}$ and was covered after the care. Substances used for the care of the umbilicus were antiseptics (e.g., alcohol, silver sulfadiazine, iodine, chlorhexidine; and dyes such as triple dye, gentian violet, acriflavine and eosin) and/or topical application of antibiotics (e.g., bacitracin, neomycin, nitrofurazone, or tetracycline), or moisture absorbing powders ${ }^{17}$. The current trend in developed countries is towards dry cord care ${ }^{14,17}$. These principles of care for developed countries are supported also by the American Academy of Pediatrics (AAP) $)^{18}$ and $\mathrm{WHO}^{19}$. The umbilical area should not be covered ${ }^{20}$ with anything, so that it stays dry and clean.

\section{Objectives}

The aim of this investigation was therefore to study whether the Slovenian and Croatian maternity hospitals practices are in concordance with the latest evidence regarding the optimal procedures after the birth of the newborn with regard to umbilical cord handling and the first care of the umbilicus. The main fields of interest were: the time of clamping the umbilical cord after the birth and comprehension of DUCC; first care of the umbilicus; and whether the procedures and practices promote dry care of the umbilicus.

\section{Materials and Methods}

The study was based on an empirical survey research approach and quantitative research paradigms. 
A causal and non-experimental method of empirical research was used. Literature review of professional and scientific references was upgraded with quantitative research.

\section{Instrument}

Research instrument was a questionnaire designed by researchers from the Faculty of Health Sciences Ljubljana in cooperation with midwifery associations from Slovenia and Croatia. It was composed of descriptive and numerical scales to rate the participants' opinions and some open and close ended questions with a variety of answers. Cronbach's coefficient alpha showed sufficient reliability ( $\mathrm{rtt}>0.763$ ) and validity (the first factor analysis explained 24.59\%) of the questionnaire.

In order to establish the effectiveness of the questions as an investigative tool, the questionnaire, upon completion of the first draft, was sent to ten randomly selected clinical mentors and faculty teachers to evaluate comprehension. Based on their observations, the final questions were drawn up; no major content changes were made.

\section{Sample description}

A purposive sample was used. Leaders of midwifery teams in all Slovenian $(\mathrm{n}=14)$ and all Croatian $(n=35)$ maternity hospitals were included in the study. Proportionally, the sample consisted of 33 participants (67\% response rate), i.e. 10 Slovenian maternity hospitals (71\% response rate) and 23 Croatian hospitals (66\% response rate).

\section{Study design}

The survey study was designed as doctrine comparison between Slovenian and Croatian maternity hospitals. In the article, we present the following research items:

- the time of umbilical cord clamping;

- comprehension of DUCC;

- first care of the umbilicus - application of medicaments;

- first care of the umbilicus - type of the disinfectant applied;

- the practice of covering the umbilicus; and

- material for covering the umbilicus.

The study was conducted in 2013. The team midwives of delivery departments voluntarily participated in the study on the basis of a declaration of voluntary participation and personal data protection. In line with the confidentiality agreement, the researchers had bound themselves to use the data collected for the research purposes only. The questionnaires were also approved by the Midwifery Chair at the Faculty of Health Sciences Ljubljana.

\section{Data analysis}

On data analysis, descriptive statistics and frequency distribution (f, F\%) of attributive and numerical variables was used. The independence hypothesis was tested with the $\chi^{2}$-test. The Kullback $2 \hat{\mathrm{I}}$-test was calculated in cases where the conditions for the theoretical frequencies of the $\chi^{2}$-test were not fulfilled. We used factor analysis (proportion of explained variance by the first factor) to determine the validity of the research instrument and Cronbach's coefficient alpha to determine the reliability of the instrument. The adequacy of the correlation matrix for factorization was assessed with the KMO test (its value was 0.794). The data are shown in tables.

\section{Results}

Research findings are shown in tables and are contextually divided chronologically according to the first care of the newborn.

Table 1 presents the prescribed time when the umbilical cord is clamped. The majority of maternity hospitals used to clamp the cord after it has stopped pulsating, however, there were some that still clamped it immediately after the birth. Differences between the groups in the answers on the time of cord clamping were not statistically significant ( $2 \hat{\mathrm{I}}=1.437, g=3$, $\mathrm{p}=0.697$ ).

Answers of the maternity hospitals regarding their understanding of DUCC are shown in Table 2. It is obvious that the majority of Croatian maternity hospitals comprehended DUCC as clamping after the cord had stopped pulsating, while the answers of Slovenian maternity hospitals were more dispersed, but altogether (88\%) still in favor of clamping at 1 minute after the birth.

Despite the great difference in the proportion of Slovenian and Croatian maternity hospitals that defined DUCC as clamping after the pulsation, the results showed no statistically significant differences be- 
Table 1. Timing of cord clamping

\begin{tabular}{|c|c|c|c|c|c|c|c|}
\hline \multicolumn{3}{|c|}{$\begin{array}{l}\text { When do you clamp cord in your } \\
\text { maternity hospital in normal deliveries? }\end{array}$} & $\begin{array}{l}\text { Immediately } \\
\text { after birth }\end{array}$ & $\begin{array}{l}\text { After it stops } \\
\text { pulsating }\end{array}$ & $\begin{array}{l}3 \text { minutes } \\
\text { after birth }\end{array}$ & Other & Total \\
\hline \multirow[t]{2}{*}{ Country } & Slovenia & $\begin{array}{l}\text { Frequency } \\
\text { Percent }\end{array}$ & $\begin{array}{l}1 \\
10.0\end{array}$ & $\begin{array}{l}8 \\
80.0\end{array}$ & $\begin{array}{l}0 \\
0.0\end{array}$ & $\begin{array}{l}1 \\
10.0\end{array}$ & $\begin{array}{l}10 \\
100.0\end{array}$ \\
\hline & Croatia & $\begin{array}{l}\text { Frequency } \\
\text { Percent }\end{array}$ & $\begin{array}{l}1 \\
4.3\end{array}$ & $\begin{array}{l}20 \\
87.0\end{array}$ & $\begin{array}{l}1 \\
4.3\end{array}$ & $\begin{array}{l}1 \\
4.3\end{array}$ & $\begin{array}{l}23 \\
100.0\end{array}$ \\
\hline \multicolumn{2}{|l|}{ Total } & $\begin{array}{l}\text { Frequency } \\
\text { Percent }\end{array}$ & $\begin{array}{l}2 \\
6.1\end{array}$ & $\begin{array}{l}28 \\
84.8\end{array}$ & $\begin{array}{l}1 \\
3.0\end{array}$ & $\begin{array}{l}2 \\
6.1\end{array}$ & $\begin{array}{l}33 \\
100.0\end{array}$ \\
\hline
\end{tabular}

Kullback $2 \hat{\mathrm{I}}$ test $(2 \hat{\mathrm{I}}=1.437, \mathrm{~g}=3, \mathrm{p}=0.697) ; \mathrm{g}=$ degree of freedom; $\mathrm{p}=$ level of statistical significance

Table 2. Comprehension of delayed umbilical cord clamping (DUCC)

\begin{tabular}{|c|c|c|c|c|c|c|c|}
\hline \multicolumn{3}{|c|}{ What do you consider as DUCC? } & $\begin{array}{l}\text { Clamping } \\
\text { after the cord } \\
\text { stops pulsating }\end{array}$ & $\begin{array}{l}\text { Clamping } \\
\text { of the cord } \\
\text { after } 1 \text { minute }\end{array}$ & $\begin{array}{l}\text { Clamping } \\
\text { the cord after } \\
3 \text { minutes } \\
\end{array}$ & Other & Total \\
\hline \multirow[t]{2}{*}{ Country } & Slovenia & $\begin{array}{l}\text { Frequency } \\
\text { Percent }\end{array}$ & $\begin{array}{l}4 \\
44.4\end{array}$ & $\begin{array}{l}2 \\
22.2\end{array}$ & $\begin{array}{l}2 \\
22.2\end{array}$ & $\begin{array}{l}1 \\
11.1\end{array}$ & $\begin{array}{l}9 \\
100.0\end{array}$ \\
\hline & Croatia & $\begin{array}{l}\text { Frequency } \\
\text { Percent }\end{array}$ & $\begin{array}{l}17 \\
73.9\end{array}$ & $\begin{array}{l}1 \\
4.3\end{array}$ & \begin{tabular}{|l|}
4 \\
17.4
\end{tabular} & $\begin{array}{l}1 \\
4.3\end{array}$ & \begin{tabular}{|l|}
23 \\
100.0
\end{tabular} \\
\hline \multicolumn{2}{|l|}{ Total } & $\begin{array}{l}\text { Frequency } \\
\text { Percent }\end{array}$ & $\begin{array}{l}21 \\
65.6\end{array}$ & \begin{tabular}{|l|}
3 \\
9.4
\end{tabular} & \begin{tabular}{|l|}
6 \\
18.8 \\
\end{tabular} & $\begin{array}{l}2 \\
6.2\end{array}$ & \begin{tabular}{|l|}
32 \\
100.0
\end{tabular} \\
\hline
\end{tabular}

Kullback $2 \hat{\mathrm{I}}$ test $(2 \hat{\mathrm{I}}=3.344, \mathrm{~g}=3, \mathrm{p}=0.342)$; $\mathrm{g}=$ degree of freedom; $\mathrm{p}=$ level of statistical significance

Table 3. First care of the umbilicus - application of medicaments

\begin{tabular}{|c|c|c|c|c|c|c|c|}
\hline \multicolumn{3}{|c|}{$\begin{array}{l}\text { What do you apply on the umbilicus } \\
\text { after cutting the cord? }\end{array}$} & Antibiotic & Antiseptic & Nothing & Other & Total \\
\hline \multirow[t]{2}{*}{ Country } & Slovenia & $\begin{array}{l}\text { Frequency } \\
\text { Percent }\end{array}$ & $\begin{array}{l}0 \\
0\end{array}$ & $\begin{array}{l}9 \\
90.0\end{array}$ & $\begin{array}{l}1 \\
10.0\end{array}$ & $\begin{array}{l}0 \\
0\end{array}$ & $\begin{array}{l}10 \\
100.0\end{array}$ \\
\hline & Croatia & $\begin{array}{l}\text { Frequency } \\
\text { Percent }\end{array}$ & $\begin{array}{l}1 \\
4.5\end{array}$ & $\begin{array}{l}12 \\
54.5\end{array}$ & $\begin{array}{l}8 \\
36.4\end{array}$ & $\begin{array}{l}1 \\
4.5\end{array}$ & $\begin{array}{l}22 \\
100.0\end{array}$ \\
\hline \multicolumn{2}{|l|}{ Total } & $\begin{array}{l}\text { Frequency } \\
\text { Percent }\end{array}$ & $\begin{array}{l}1 \\
3.1\end{array}$ & $\begin{array}{l}21 \\
65.6\end{array}$ & $\begin{array}{l}9 \\
28.1\end{array}$ & $\begin{array}{l}1 \\
3.1\end{array}$ & $\begin{array}{l}32 \\
100.0\end{array}$ \\
\hline
\end{tabular}

Kullback $2 \hat{\mathrm{I}}$ test $(2 \hat{\mathrm{I}}=4.788, \mathrm{~g}=3, \mathrm{p}=0.188) ; \mathrm{g}=$ degree of freedom; $\mathrm{p}=$ level of statistical significance

Table 4. First care of the umbilicus - type of the disinfectant applied

\begin{tabular}{|l|l|l|l|l|l|l|l|l|}
\hline $\begin{array}{l}\text { Which disinfectant do you apply on the } \\
\text { umbilicus after cutting the cord? }\end{array}$ & $\begin{array}{l}\text { 2\% potassium } \\
\text { permanganate }\end{array}$ & Braunol & Octenisept & Iodine & Alcohol & Total \\
\hline Country & Slovenia & $\begin{array}{l}\text { Frequency } \\
\text { Percent }\end{array}$ & 6 & 85.7 & 1 & 0 & 0 & 0 \\
\end{tabular}

Kullback $2 \hat{\mathrm{I}}$ test $(2 \hat{\mathrm{I}}=25.008, \mathrm{~g}=4, \mathrm{p}=0.000) ; \mathrm{g}=$ degree of freedom; $\mathrm{p}=$ level of statistical significance 


\section{Table 5. Covering the umbilicus}

\begin{tabular}{|l|l|l|l|l|l|}
\hline \multicolumn{2}{|l|}{$\begin{array}{l}\text { Do you cover the umbilicus } \\
\text { after the first care? }\end{array}$} & Yes & No & Total \\
\hline Country & Slovenia & Frequency & 5 & 5 & 10 \\
\cline { 3 - 6 } & Percent & 50.0 & 50.0 & 100.0 \\
\cline { 2 - 6 } & Croatia & Frequency & 22 & 1 & 4 \\
\cline { 3 - 6 } & Percent & 95.7 & 4.3 & 100.0 \\
\hline
\end{tabular}

$\chi^{2}$-test $\left(\chi^{2}=9.764, \mathrm{~g}=1, \mathrm{p}=0.002\right) ; \mathrm{g}=$ degree of freedom; $\mathrm{p}=$ level of statistical significance

\section{Table 6. Material for covering the umbilicus}

\begin{tabular}{|c|c|c|c|c|c|}
\hline \multicolumn{3}{|c|}{$\begin{array}{l}\text { What remedies do you use to } \\
\text { cover the umbilicus after the } \\
\text { first care? }\end{array}$} & $\begin{array}{l}\text { Sterile } \\
\text { pad }\end{array}$ & $\begin{array}{l}\text { Sterile } \\
\text { pad, } \\
\text { covered } \\
\text { by elastic } \\
\text { bandage }\end{array}$ & Total \\
\hline \multirow[t]{4}{*}{ Country } & \multirow[t]{2}{*}{ Slovenia } & Frequency & 4 & 1 & 5 \\
\hline & & Percent & 80.0 & 20.0 & 100.0 \\
\hline & \multirow[t]{2}{*}{ Croatia } & Frequency & 21 & 0 & 21 \\
\hline & & Percent & 100.0 & 0 & 100.0 \\
\hline
\end{tabular}

$\chi^{2}$-test $\left(\chi^{2}=3.473, g=1, p=0.062\right) ; g=$ degree of freedom; $\mathrm{p}=$ level of statistical significance

tween the answers of Croatian and Slovenian maternity hospitals ( $2 \hat{\mathrm{I}}=3.344, \mathrm{~g}=3, \mathrm{p}=0.342)$.

Table 3 summarizes practices regarding the treatment of the umbilical cord stump. Almost all Slovenian hospitals still used antiseptic medicaments on the stump after the birth, in comparison to only half of the Croatian maternity hospitals. A higher proportion of the latter preferred dry cord care. No Slovenian maternity hospital used antibiotics, in contrast to particular Croatian maternity hospitals. Despite the proportional differences, statistical tests showed no statistically significant between the groups (Table 3).

Different substances used for the first care of the stump that maternity hospitals cited in the open-ended question are listed in Table 4. Braunol is a preparation of iodine, while Octenisept is a combination of octenidine and phenoxyethanol. The majority of Slovenian maternity hospitals used $2 \%$ potassium permanganate, while Croatian maternity hospitals most frequently used Octenisept. Iodine preparations (Braunol and Iodine) were used by a similar proportion of Croatian (16.7\%) and Slovenian (14.3\%) maternity wards.
Table 4 shows results on the use of different disinfectants, with statistically significant differences $(2 \hat{\mathrm{I}}=$ 25.008, $g=4, p=0.000$ ) between the Slovenian and Croatian maternity hospital practices.

The next area of the authors' interest was the doctrine regarding the umbilical cord stump dressing. Answers to this question are shown in Table 5 . There were statistically significant differences in the results regarding covering the umbilicus after the first care ( $2 \hat{\mathrm{I}}=9.764, \mathrm{~g}=1, \mathrm{p}=0.002)$. The vast majority of Croatian maternity hospitals still covered the stump, whereas variable practices were reported from Slovenia, i.e. half of the maternity hospitals did and the other half did not cover the umbilical cord.

As evident from the data presented in Table 6, the majority of maternity hospitals in Slovenia and all maternity hospitals in Croatia, which reported covering the stump, used sterile pads. Only particular Slovenian hospital also used bandage. There were no statistically significant differences between the Slovenian and Croatian maternity wards in answers to this question.

\section{Discussion}

Immediate umbilical cord clamping has been shown to present a potential risk for the newborn because of the iron deficiency anemia ${ }^{21}$, which can delay normal child's development at long term, even when treated ${ }^{22}$. Recent studies focus also on the aspect of deprivation of stem cells in case of IUCC. IUCC can deprive a term infant of $60-100 \mathrm{~mL}$ of blood and $50 \mathrm{mg} / \mathrm{kg}$ of iron. A higher volume of blood is an essential component for establishing normal pulmonary blood flow, without compromising blood flow to other organs. IUCC is an intervention that was accepted without any evidence of benefits. It persisted for so long that delayed umbilical cord clamping (DUCC) is now seen as an intervention that has to be proven, despite the fact that actually IUCC is the intervention that disrupts normal physiological birth processes. On the other hand, DUCC is a low-tech, low-cost birth practice $^{1}$. The procedure offers more gentle transition to extrauterine life and provides the baby with necessary time for adjustment ${ }^{1}$, with no harm for the mother ${ }^{5}$. With DUCC, the newborn gets more red blood cells and hematopoietic stem cells and $30 \%$ of additional blood volume that is important for respiratory function $^{1}$. It is therefore the recommended intervention, supported by the majority of international professional 
organizations for term infants. Furthermore, Slovenian neonatologists ${ }^{23}$ and Slovenian national guidelines $^{1}$ support DUCC, however, they define it as clamping 30-60 seconds after the birth. In Croatia, there are no position statements of the professional organizations regarding this issue; however, the Croatian Association for Promotion of Midwifery and the Croatian Chamber of Midwives outline that the opinions about DUCC still vary, whereas midwives working on labor wards support DUCC ${ }^{24}$.

According to our study, more than $80 \%$ of responding maternity hospitals in Croatia and Slovenia practice DUCC. The expectant third stage of labor that also includes DUCC is closely connected to the non-medicalized approach towards childbirth that does not include induction and augmentation of labor ${ }^{4}$. A lot of births in Slovenia are induced; the national Birth Study has reported a $21.3 \%$ induction rate and $40 \%$ of augmented deliveries ${ }^{25}$. This could be a restrain in practicing DUCC. The practices have definitely improved; in 2012, only $33 \%$ of the Slovenian maternity hospitals reported practicing expectant third stage of labor ${ }^{26}$.

Despite the fact that the time for DUCC is defined differently among studies, Begley et al..$^{2}$ report that it is crucial for the cord to stop pulsating before it is clamped. As seen from the results of our study, the majority of Slovenian and Croatian maternity wards also defined it this way and the majority of them followed this practice.

Considering neonatal care, Trotter recommends that minimal approach to skin care be adopted ${ }^{20}$. Topical antibiotics can be used to treat umbilical cord infections, however, their use is sensible only when the infection is already present. Most of sticky cords are the result of saprophytic action and require hygiene measures rather than antibiotics ${ }^{22}$. The possible side effect of topical antimicrobials is delay in the cord separation time ${ }^{15}$, which can potentially increase the risk of bacterial entry ${ }^{27}$. Also, NICE guidelines ${ }^{28}$ support dry stump care. The authors did not find any position statements of the international professional organizations regarding the umbilical cord care, however, some Slovenian neonatologists still recommend antiseptic prophylaxis of the umbilical cord stump ${ }^{23}$ and application of $6 \%$ potassium permanganate is prescribed in the national guidelines for umbilical cord care in the delivery room ${ }^{29}$. This can explain the results on the practice of Slovenian maternity hospitals. In Croatia, there are no national guidelines for stump care, however, we found an article reporting a study among Cro- atian maternity hospitals regarding the stump care ${ }^{30}$, which ascertains the need of national guidelines on this issue. Practices of both countries are in contrast to Cochrane reviews ${ }^{16,17}$, which revealed that no antiseptic was found to be advantageous for the prevention of cord infection compared with dry cord care in hospital settings and concluded with a recommendation on dry cord care being sufficient in developed countries.

According to dry cord care, the navel string should not be covered, however, according to the results of our study, $50 \%$ of the Slovenian maternity clinics and almost all Croatian maternity hospitals still cover the stump. The result reflects the findings of a Croatian national study by Oštrić and Finderle ${ }^{30}$. This kind of treatment is not prescribed by the Slovenian national guideline ${ }^{29}$; the authors did not find any specific instructions for Croatian practices or a position statement of international professional organizations.

\section{Conclusion}

In the majority of the Slovenian and Croatian maternity hospitals, the practices of cord clamping are in accordance with the evidence promoting physiology of the third stage of labor as optimal care for the newborn and suggesting DUCC accordingly. However, we must also bear in mind well-being of the woman; if active management of the third stage of labor may in certain situations prove crucial for her health, this method of management should be used.

Improvements could be made regarding stump care, where dry cord care is recommended by evidence; however, it is still not commonly practiced in Slovenian and Croatian maternity hospitals. National guidelines should be improved or developed. Further research is needed to tackle other segments of the first care of the newborn.

\section{Acknowledgment}

We would like to thank presidents of the Slovenian and Croatian midwifery associations for their help in data collection.

\section{References}

1. Mercer J, Erikson-Owens D. Evidence for neonatal transition and the first hour of life. In: Walsh D, Downe S, eds. Essential Midwifery Practice: Intrapartum Care. Sussex: Wiley-Blackwell; 2011. p 81-100.

2. Begley CM, Guilliland K, Dixon L, Reilly M, Keegan C. Irish and New Zealand midwives' expertise in expectant manage- 
ment of the third stage of labour: the 'MEET'study. Midwifery. 2012;28:733-9. doi: 10.1016/j.midw.2011.08.008.

3. Thorpe J, Anderson J. Supporting women in labour and birth. In: Pairman S, Pincombe J, Thorogood C, Tracy S, eds. Midwifery: Preparation for Practice. $3^{\text {rd }}$ edn. Sydney: Churchill Livingstone, Elsevier; 2014. p 626-65.

4. Walsh D. Evidence and Skills for Normal Labour and Birth: A Guide for Midwives. $2^{\text {nd }}$ edn. London: Routledge; 2012.

5. McDonald SJ, Middleton P, Dowswell T, Morris PS. Effect of timing of umbilical cord clamping of term infants on maternal and neonatal outcomes. Evidence Based Child Health. 2013; 9:303-97. doi: 10.1002/14651858.CD004074.pub3.

6. Enkin MM, Keirse MJNC, Neilson J, Crowther C, Duley L, Hodnett E, Hofmeyr J. The third stage of labour. In: Enkin MM, et al. A Guide to Effective Care in Pregnancy and Childbirth. Oxford: Oxford University Press; 2000. p 300-6.

7. Holmes D, Baker PN. Labour. In: Holmes D, Baker PN, eds. Midwifery by Ten Teachers. NY: Hodder Arnold; 2006. p 209-38.

8. NICE, 2014. [Internet]. Intrapartum care: care of healthy women and their babies during childbirth. [cited 2015 July 15]. Available from: http://www.nice.org.uk/guidance/cg190/resources/guidance-intrapartum-care-care-of-healthy-womenand-their-babies-during-childbirth-pdf

9. Hendrix E. Routine interventions during normal labour and birth... are they really necessary? In: Donna S, ed. Promoting Normal Childbirth; Research, Reflections and Guidelines Chester: Fresh Heart Publishing, Ltd.; 2011. p 6-20.

10. WHO. Delayed umbilical cord clamping for improved maternal and infant health and nutrition outcomes: Guideline. Geneva: WHO; 2014.

11. RCOG, 2015. [Internet]. Position statement on: Timing of clamping the umbilical cord analysed in new opinion paper. [cited 2015 July 16]. Available from: https://www.rcog.org.uk/ en/news/rcog-release-timing-of-clamping-the-umbilicalcord-analysed-in-new-opinion-paper/

12. ACOG, 2012. [Internet]. Committee opinion: Timing of umbilical cord clamping after Birth. [cited 2015 July 15]. Available from: http://www.acog.org/Resources-And-Publications/Committee-Opinions/Committee-on-Obstetric-Practice/Timing-of-Umbilical-Cord-Clamping-After-Birth

13. England C. The neonate. In: Marshall J, Raynor M, eds. Myles Textbook for Midwives. $16^{\text {th }}$ edn. Edinburgh: Churchill Livingstone, Elsevier; 2014. p 590-617.

14. Blackburn Tucker S. Integumentary system. In: Blackburn Tucker S, ed. Maternal, Fetal and Neonatal Physiology. $3^{\text {rd }}$ edn. St. Louis: Saunders, Elsevier; 2007. p 517-20.

15. Aygun C, Subasi A, Kucukoduk S. Timing of umbilical cord separation and neonatal intensive care units. Am J Perinatol. 2005;22:249. doi: 10.1055/s-2005-870661

16. Zupan J, Garner P, Omari AAA. Topical umbilical cord care at birth. Cochrane Database of Systematic Reviews 2004, Issue 3. Art. No.: CD001057. doi: 10.1002/14651858.CD001057.pub2
17. Imdad A, Bautista RMM, Senen KAA, Uy MEV, Mantaring III JB, Bhutta ZA. Umbilical cord antiseptics for preventing sepsis and death among newborns. Cochrane Database of Systematic Reviews 2013, Issue 5. Art. No.: CD008635. doi: 10.1002/14651858.CD008635.pub2

18. AAP. Committee statement: a Report of the Committee on Infectious Diseases. $26^{\text {th }}$ edn. Elk Grove Village: American Academy of Pediatrics; 2003.

19. WHO. Care of the umbilical cord: a review of the evidence. Geneva: World Health Organization; 1998: WHO/RHT/ MSM/98.4.

20. Trotter S. Neonatal skincare. In: Lumsden H, Holmes D, eds. Care of the Newborn by Ten Teachers. London: Hodder Arnold; 2010. p 78-88.

21. Hutton EK, Hassan ES. Late vs early cord clamping of the umbilical cord in full-term neonates: systematic review and meta-analysis of controlled trials. JAMA. 2007;297(11): 1241-52. doi: 10.1001/jama.297.11.1241

22. Lozoff B, Georgieff MK. Iron deficiency and brain development. Semin Pediatr Neurol. 2006;13(3):158-65.

doi: 10.1016/j.spen.2006.08.004

23. Babnik J. Oskrba novorojenčka v porodni sobi. In: Pajntar M, Novak-Antolič Ž, Lučovnik M, eds. Nosečnost in vodenje poroda. $3^{\text {rd }}$ edn. Ljubljana: Medicinski razgledi. 2015. p 439-43. (in Slovene)

24. Andrić Đ, Cukin M, Leder M, Nosil I, Šćulac E. [Internet]. Rano ili kasno podvezivanje pupkovine. Primaljski vjesnik 2013;15:41-4. [cited 2015 July 20]. Available from: http:// www.hupp.hr/baza/upload/File/pv_15_tisak+basler_web.pdf (in Croatian)

25. Wagner M. Evolucija k žensko osrediščeni obporodni skrbi. In: Drglin Z, ed. Rojstna mašinerija. Sodobne porodne vednosti in prakse na Slovenskem. Koper: Univerza na Primorskem, Znanstveno-raziskovalno središče, Založba Annales: Zgodovinsko društvo za južno Primorsko; 2007. p 17-22. (in Slovene)

26. Ramovš P, Prelec A, Mivšek AP. Odgovornosti babice glede pregleda posteljice: raziskava o pristopih v slovenskih porodnišnicah. Obzornik zdravstvene nege 2015;49(2):149-53. (in Slovene)

27. Novack AH, Mueller B, Ochs H. Umbilical separation in the normal newborn. Am J Dis Child. 1988;142(2):220-3.

28. NICE, 2015. [Internet]. Routine postnatal care of women and their babies. [cited 2015 July 15]. Available from: https: //www.nice.org.uk/guidance/cg37

29. Zbornica zdravstvene in babiške nege Slovenije-ZZBNS, 2014. [Internet]. Nacionalni protokoli aktivnosti zdravstvene in babiške nege: Zdravstvena nega popka novorojenčka. [cited 2015 July 15]. Available from: http://www.zbornica-zveza.si/ sites/default/files/doc_attachments/08.01_priloga_zdravstvena_nega_popka_novorojencka.pdf (in Slovene)

30. Oštrić A, Finderle B. Skrb o pupkovini i pupčanom bataljku. Primaljski vjestnik 2012;12:60-6. (in Croatian) 


\section{Sažetak}

\section{NJEGA PUPKOVINE I BATRLJKA KOD NORMALNIH POROĐAJA U SLOVENSKIM I HRVATSKIM RODILIŠTIMA}

\section{A. P. Mivšek, P. Petročnik, M. Skubic, T. Škodič Zakšek i A. Jug Došler}

Cilj rada bio je istražiti postupke vezane uz njegu pupkovine i batrljaka u rodilišstima u Sloveniji i Hrvatskoj. Studija je bila temeljena na metodama empirijskog upitničkog istraživanja pomoću upitnika i kvantitativne istraživačke paradigme, a obuhvatila je sva slovenska rodilišta $(n=14)$ i sva hrvatska rodilišta $(n=35)$. Primalje iz 14 rodilišta u Sloveniji i 35 rodilišta u Hrvatskoj pozvani su da sudjeluju u istraživanju. Istraživanje je provedeno 2013. godine, a sudjelovalo je 67\% slovenskih rodilišta i 66\% hrvatskih rodilišta. Primijenjene su kauzalne i ne-eksperimentalne metode empirijskog istraživanja. Instrument istraživanja bio je upitnik. Opisne statistike su pripremljene. Teza neovisnosti testirana je $\chi^{2}$-testom odnosno Kullbackovim $2 \hat{I}$-testom. Rezultati su pokazali da velika većina rodilišta primjenjuje metodu DUCC (delayed umbilical cord clamping), tj. pupkovina se klema tek nakon što prestane pulsirati. Samo 10\% slovenskih rodilišta u odnosu na 36,4\% hrvatskih rodilišta prakticira suhu njegu batrljka. U ostalim rodilištima se batrljak dezinficira; u Sloveniji se za to najčešće rabi kalijev permanganat u 6\%-tnoj otopini, dok se u Hrvatskoj najčešće upotrebljava kombinacija oktenidinklorida i fenoksietanola. Većina rodilišta u Hrvatskoj $(95,7 \%)$ i dalje pokrivaju batrljak gazom, dok to nije najčešća praksa u Sloveniji. Autori procjenjuju da su najzastupljenije metode za njegu pupkovine koje se primjenjuju u slovenskim i hrvatskim rodilištima u skladu s dokazima, dok se poboljšanja mogu primijeniti u njezi batrljka; preporuča se suhu njegu bez pokrivanja.

Ključne riječi: Novorođenče; Pupkovina; Rodilišta; Slovenija; Hrvatska; Empirijsko istraživanje; Primaljstvo; Dezinficijensi; Kalijer permanganat; Octenidin; Fenoksietanol 